\title{
An investigation of clothing related barriers faced by women with disabilities
}

\author{
R. Mataraarachchi ${ }^{1 *}$, N. Seram ${ }^{2}$, S.Maduwage $^{3} \&$ T.I.Galgamuwage ${ }^{4}$ \\ 1. University of Moratuwa, Sri Lanka \\ 2. University of Moratuwa, Sri Lanka \\ ${ }^{3 .}$ Ministry of Health, Sri Lanka \\ 4. University of Moratuwa, Sri Lanka
}

\begin{abstract}
Clothing can serve as a means of conveying to others the equal status in life which disabled women enjoy, as this will promote their self-confidence, self-esteem and make them feel that they are also a part of the community. When taking a holistic approach towards disability rehabilitation and implementation of an acceptable social model in disability care, it becomes apparent that the clothing related issues of women living with disability have not been addressed properly. Therefore it has become an essential need with a high demand among disabled women to fulfil in the current day society. The main objective of the study was to identify the clothing related barriers faced by those women living with disabilities in Sri Lanka and to make recommendations for further research. Semi-structured face-to-face interviews were conducted to identify the clothing barriers. Following the purposive sampling technique, ten respondents were selected. Content analysis technique was used for data analysis. Key barriers were identified and needed adaptive clothing types were categorized based on the women's activities and daily routine. It was found that the Sri Lankan retail sector did not cater to most of these requirements while adaptive clothing brands did not cater to some of the major problems faced by women with disabilities. Further studies are recommended relating to the development of new adaptive clothing products.
\end{abstract}

Keywords: Adaptive clothing, Physical disabilities, Women with disabilities

\section{Introduction}

Disability is defined as, "an umbrella term for difficulties encountered due to impairments (problems in body functions or anomalies in body structure), activity limitations (difficulties in executing activities) and participation restrictions (problems with involvement in any area of life)" (WHO, 2018). According to World Bank reports, $15 \%$ of the world's population (one billion people in total) is experiencing some form of disability, either physical, mental or both, congenital or occurring later, or due to accident; the disability may be temporary or permanent (World Bank Group, 2018).

Clothes are an essential adjunct to every human, without which that person cannot engage in the activities of daily living; clothes also contribute significantly to his/ her self-confidence and selfesteem (Klerk \& Ampousah, 2003). For those challenged by disabilities getting dressed can be quite frustrating, as they have to struggle on a daily basis with dexterity issues involving fastenings like hooks, buttons, zippers, tags, and prominent seams etc. (Sarcone, 2017; Schneider, 2015). This is mainly due to the fact that the differently abled find it difficult to wear the same clothing as the able bodied individuals due to physical weakness, limited mobility, or impaired cognition (Banks, 2001). Thus, such impediments may pose a risk to the affected persons' mental health by lowering their selfesteem and dignity (Imran, Drean \& Adolphe, 2017). This clearly shows that a design intervention is imperative to overcome the challenges posed by 'unfriendly' clothing to the disabled. But until 
recently, this issue had been overlooked or ignored by the apparel industry at large, possibly due to the social misperceptions surrounding it, such as:

- the disabled are not fashion conscious

- there is only a small market for these products

- no defined requirement for specialized clothing for the disabled

- clothing for the disabled cannot be mass produced (Zhdanova, 2014)

A few fashion retailers have identified the market gap and realized that it is a growing market. So they introduced special clothing for disabled consumers recently, trying to create equilibrium between fashion and function, by offering products that adapt to the wearer (Moniuszko, 2018). As a result, a few clothing solutions were proposed to minimize the clothing related challenges faced by people with disabilities. Some of the clothing solutions that could be observed in garments designed for people with disabilities are presented in Table 1 .

Table 1: A few clothing solutions that could be observed in garments designed for people with disabilities

\begin{tabular}{ll}
\hline Purpose & Clothing solution \\
\hline For convenience in fastening & Velcro-type closures \\
\cline { 2 - 2 } & One-handed zippers \\
\cline { 2 - 2 } & Front closure bras \\
\cline { 2 - 2 } & Magnetic closures/ buttons \\
\hline Alternatives for putting on clothes & Open-back \\
\hline $\begin{array}{l}\text { For those who cannot lift their arms to put } \\
\text { on clothes }\end{array}$ & Zip-off sleeves \\
\hline For those who have difficulty in handling \\
zipper fly fastenings/ hard seams & Adjustable waistline/ pull on pants \\
\hline Alternative ways of putting on clothes & Easy-open necklines/ easy back openings \\
\hline $\begin{array}{l}\text { For wheelchair users } \\
\text { having immobility issues in the legs }\end{array}$ & Enhanced back rise \\
\hline
\end{tabular}

\section{Clothing and disabled women}

Out of the total number of persons living with disabilities, half are women and girls (World Bank Group, 2018). In addition, the proportion of women with disabilities is higher in the lower income countries than higher income countries.

Contrary to the popular beliefs/ myths associated with disabled women, they perceive fashion as a source of self-expression, yet the clothing options available to them are highly limited. From the time 
they were affected, they have been purchasing regular clothing and customizing same to meet their special needs. Therefore, they feel they are not acknowledged by the fashion industry, which is perceived to be operating with a singular ideal of beauty (Ahmed, 2017). The lack of appropriate clothing has created a barrier that prevents them from engaging with the community freely (Kabel, McBee-Black, \& Dimka, 2016).

In the past, a few studies tried to address the requirements of women with disabilities by presenting clothing solutions/ special clothing such as garments with seamless knitting (Radvan, 2013), business clothing (Carroll, 2001), adaptive bra (Imran, Drean \& Adolphe, 2017) and occasional wear (Kidd, 2006). However, to date no manufacturer has adopted a holistic approach towards disability rehabilitation or implementation of the social model in disability care, leaving unaddressed the clothing related barriers faced by women living with disabilities. Hence, a need has arisen to address and fulfill these unmet demands in a timely manner. In Sri Lankan set up there is a wide gap between unmet need of females with disabilities and available facilities for them on clothing issues. Evidence based information on clothing requirements for females with disabilities are very limited. Therefore it is highly justifiable to conduct research on clothing related barriers faced by the females with disabilities in Sri Lanka. It would be a highly significant evidence based information for the policy makers and programme planners in the country. Thus, the main objective of the study was to identify the clothing related barriers faced by the women living with disabilities in Sri Lanka and to make recommendations for further research.

\section{Methods}

Semi structured interviews were the method of data collection. Based on the expert opinion and the extensive literature review two interview guides were developed. Translation and pre testing were done. Of the two interviewer guides one was for the selected females with disabilities and the other guide was for their caregivers. Eleven items were included in the guide developed for the females with disabilities. Ten items were included for the interviewer guide which was developed for the caregivers. Variables included for the interviewer guide were social demographic background of the sample, the details about their disability, daily living activities of the individual, and the issues relating to the clothing they faced. Data collectors were well trained under the supervision of experts in the field.

Ten females with disabilities were selected from health institutions both in state and private sector at western province using random sampling technique based on inclusion and exclusion criteria. Inclusion criteria were the permeant resident of western province, confirmed cases of disability with the age between 20 years to 65 years. They appeared to be a good representation of the differently abled community in Sri Lanka. All participants were fully informed of the purpose of the research and their willingness to participate in the interviews was ascertained. Interviews for the data collection were conducted at their residences maintaining privacy. This was done to encourage the differently abled individuals to speak freely of their real life experiences, and allow them to provide suggestions on how clothes should be designed to fit their needs, wherever possible and to minimize stigma.

The voice recordings of ten interviews were transcribed and the findings analyzed qualitatively. In the analysis of data, the principles of content analysis (Erlingsson \& Brysiewicz, 2017) were adopted to identify the emerging themes/ ideas. Accordingly, key barriers and special needs for adaptive clothing were categorized based on their activities and daily routine. 


\section{Results}

An analysis of the personal information of 10 female with disabilities revealed that they were from diverse family backgrounds, with their ages ranging from 24 to 63 years. Since the nature of the disability and the extent of the physical limitation determines the type of clothing required (Carroll, 2001), the first thing the study focused on was to identify the type of disability and the limitations suffered by each of the 10 women. Then it came to light that the physical limitations varied according to the type of disability. The type of disability and the associated physical limitations of the respondents can be summed up as shown in Table 2 .

Table 2: Type of disability and associated limitations of the respondents

\begin{tabular}{|c|c|c|c|}
\hline $\begin{array}{l}\text { Int. } \\
\text { no: }\end{array}$ & $\begin{array}{l}\text { Age } \\
\text { (years) }\end{array}$ & Type of disability & Associated physical limitations \\
\hline 01 & 32 & $\begin{array}{l}\text { Congenital, Developmental- } \\
\text { Upper body (brain) and lower } \\
\text { body (legs) }\end{array}$ & $\begin{array}{l}\text { Unsteady walk, difficulty in eating food as she cannot } \\
\text { hold food in her fingers properly, cannot write. }\end{array}$ \\
\hline 02 & 26 & $\begin{array}{l}\text { Congenital, Developmental- } \\
\text { Upper body (brain, right arm) } \\
\text { and lower body (right leg) }\end{array}$ & $\begin{array}{l}\text { Difficulty in eating food as she cannot hold food in her } \\
\text { fingers, cannot hold a mug or other physical objects, } \\
\text { cannot write as she cannot hold a pencil/ pen, difficulty in } \\
\text { walking. }\end{array}$ \\
\hline 03 & 41 & $\begin{array}{l}\text { Congenital, Acquired- } \\
\text { Lower body (legs) }\end{array}$ & $\begin{array}{l}\text { Cannot walk, cannot sit, cannot turn, cannot cross her } \\
\text { legs, cannot bend her knees, and cannot bend her } \\
\text { backbone; can only lie on bed. }\end{array}$ \\
\hline 04 & 34 & $\begin{array}{l}\text { Congenital, Developmental- } \\
\text { Upper body (arms and trunk) } \\
\text { and lower body (legs) }\end{array}$ & $\begin{array}{l}\text { Cannot walk, cannot lift her hands and needs help in } \\
\text { dressing herself. Can move from wheelchair to bed but } \\
\text { needs help when moving from the bed to the wheelchair. } \\
\text { Needs help in washing/ bathing herself. }\end{array}$ \\
\hline 05 & 43 & $\begin{array}{l}\text { Congenital- } \\
\text { Lower limb (below hip) }\end{array}$ & $\begin{array}{l}\text { Cannot walk properly, cannot sit on the floor, cannot } \\
\text { bend her knee, cannot do any hard work at home, and } \\
\text { cannot even do grocery shopping. }\end{array}$ \\
\hline 06 & 59 & $\begin{array}{l}\text { Acquired- } \\
\text { Lower limb (below hip, spinal } \\
\text { cord) }\end{array}$ & $\begin{array}{l}\text { Cannot walk, numbness in legs, stiffness in muscles when } \\
\text { maintaining the same position. }\end{array}$ \\
\hline 07 & 63 & $\begin{array}{l}\text { Acquired- } \\
\text { Spinal cord }\end{array}$ & $\begin{array}{l}\text { Cannot walk, falls forward when the back is not } \\
\text { supported, bedridden at home. }\end{array}$ \\
\hline 08 & 45 & $\begin{array}{l}\text { Acquired- } \\
\text { Upper limb (between elbow and } \\
\text { wrist of right hand) }\end{array}$ & $\begin{array}{l}\text { Cannot lift the arm and do any work. Cannot perform } \\
\text { household chores. Difficulty in dressing herself alone. } \\
\text { Needs support of another. }\end{array}$ \\
\hline 09 & 59 & $\begin{array}{l}\text { Acquired- } \\
\text { Lower limb (below knee) }\end{array}$ & Cannot perform household chores, bathe or dress herself. \\
\hline 10 & 24 & $\begin{array}{l}\text { Acquired- } \\
\text { Lower limb (between hip and } \\
\text { knee) }\end{array}$ & $\begin{array}{l}\text { Can walk with the walker. Bedridden much of the time. } \\
\text { Cannot sit upright. Cannot dress herself or use the } \\
\text { washroom alone. She cannot do any household chores. }\end{array}$ \\
\hline
\end{tabular}

\section{Clothing related barriers}

The main focus of this study was on clothing related barriers; the key clothing barriers of differently abled women were categorized based on their daily routine and other activities they engaged in, for ease of understanding. 
The clothing barriers related to their daily routine were explored using six main activities: day-to-day dressing, using the bathroom, sleeping/ lying on the bed, changing posture, moving from one place to another, and using supportive equipment. Within these main activities/ daily routines, subroutines were also identified.

Almost all the respondents claimed they were facing difficulties in putting on and taking off the garments and handling the fastenings in their clothes during daily activities. According to Case 1 (caregiver) "She cannot button her garments and she cannot wear panties as they are too tight for her and difficult for the caregiver to pull up." The other main clothing barriers are the difficulty in movement after wearing clothing and the lack of comfort in their present clothing. As Case 10 stated, "I cannot wear any tight clothes. I like to wear jeans but due to the medical clamps I cannot wear them." Table 3 provides a detailed picture of the clothing related barriers experienced by the differently abled women in their daily routine within Sri Lanka.

Table 3: Clothing related barriers encountered in their daily routine.

\begin{tabular}{|c|c|c|}
\hline Activity & Sub activity & Barrier identified \\
\hline \multirow[t]{2}{*}{ Day-to-day dressing } & & Donning and doffing (Put on/ take off ) \\
\hline & & Difficulty in handling fastening \\
\hline \multirow[t]{6}{*}{ Using the bathroom } & \multirow[t]{2}{*}{$\begin{array}{l}\text { Accessing the toilet } \\
\text { facilities }\end{array}$} & $\begin{array}{l}\text { Difficulty in donning and doffing (put on and take off) } \\
\text { undergarments/ outer wear }\end{array}$ \\
\hline & & Difficulty in handling fastening \\
\hline & $\begin{array}{l}\text { Handling periods } \\
\text { clothing }\end{array}$ & Difficulty in donning and doffing (put on and take off) \\
\hline & \multirow[t]{3}{*}{ Dressing } & Lack of comfort \\
\hline & & Difficulty in donning and doffing (put on and take off) \\
\hline & & Difficulty in handling fastening \\
\hline \multicolumn{2}{|l|}{ Sleeping/ lying on bed } & Discomfort due to hard seams \\
\hline \multicolumn{2}{|l|}{$\begin{array}{l}\text { Changing posture } \\
\text { (standing to sitting) }\end{array}$} & Restricted mobility due to tight clothing \\
\hline \multirow{2}{*}{\multicolumn{2}{|c|}{$\begin{array}{l}\text { Moving from one place } \\
\text { to another }\end{array}$}} & Restricted mobility due to tight clothing \\
\hline & & $\begin{array}{l}\text { Difficulty in moving around due to long and bulky } \\
\text { clothing that might get entangled with physical objects }\end{array}$ \\
\hline \multirow{6}{*}{$\begin{array}{l}\text { Difficulties caused by } \\
\text { supportive equipment } \\
\text { (Wheelchair/ Cane/ } \\
\text { Crutches/ Walker/ } \\
\text { Other) }\end{array}$} & & Difficulty in moving around due to tight clothing \\
\hline & & $\begin{array}{l}\text { Restricted mobility due to long and bulky clothing that } \\
\text { may get entangled with physical objects }\end{array}$ \\
\hline & & Discomfort due to hard seams \\
\hline & & Lack of comfort (bad fit, style, material) \\
\hline & & Suitable clothing not available \\
\hline & & Difficulty in handling fastening \\
\hline
\end{tabular}


On further examining the answers, it became evident that the women with disabilities found it difficult to buy clothing to fit their diverse body types, especially for different activities and occasions. The following quote reveals the frustration of searching for the right kind of clothing.

"I like to dress fashionably, yet in a very conservative manner. As it is difficult to wear the regular clothes, I sew my garments myself. Sometimes, I buy new clothes and alter them to match my needs. My sisters who are suffering from the same condition like to wear seductive clothes, but they find it difficult to find garments to match their bodies. They update themselves on fashion trends through Facebook" (Case 4).

In addition, it was clear that lack of comfort, inconvenient fastening methods and difficulty with the motions required to put them on are the other major clothing barriers to them. Detailed descriptions of the barriers related to clothing required for different activities are presented in Table 4 .

Table 4: Clothing related barriers in respect of other activities.

\begin{tabular}{|c|c|}
\hline $\begin{array}{l}\text { Activity for which clothes } \\
\text { are required }\end{array}$ & Barrier identified \\
\hline \multirow[t]{4}{*}{ Fitness routine/ recreational activities } & Lack of comfort (bad fit, style, material) \\
\hline & Discomfort due to hard seams \\
\hline & Suitable clothing not available \\
\hline & Difficulty of movement when wearing the clothing \\
\hline \multirow[t]{3}{*}{$\begin{array}{l}\text { Special medical procedures (e.g. } \\
\text { Exercise/ Massage/ Physiotherapy) }\end{array}$} & $\begin{array}{l}\text { Difficulties due to fastening, sometimes have to remove the } \\
\text { garment fully for the medical procedure }\end{array}$ \\
\hline & Lack of comfort (bad fit, material) \\
\hline & Suitable clothing not available \\
\hline \multirow[t]{3}{*}{ Parties/ social events/ dining out } & $\begin{array}{l}\text { Inconvenient to remove, put on and adjust when visiting } \\
\text { the ladies' toilet }\end{array}$ \\
\hline & $\begin{array}{l}\text { Free movement of legs and arms constrained when } \\
\text { dancing }\end{array}$ \\
\hline & Suitable clothing not available \\
\hline Religious activities & $\begin{array}{l}\text { Inconvenient and awkward when sitting on the floor/ } \\
\text { kneeling/ praying }\end{array}$ \\
\hline \multirow[t]{3}{*}{ During work } & Difficulty due to fastening \\
\hline & Lack of comfort (bad style, material) \\
\hline & $\begin{array}{l}\text { Restricted mobility due to too tight and sometimes too loose } \\
\text { clothing }\end{array}$ \\
\hline
\end{tabular}

\section{Conclusion and recommendation}

The research findings highlighted the fact that the study population were looking for custom made clothing that would fit their diverse body types while providing ease of movement. The customers 
also desired convenient fastening techniques to ensure ease of handling when putting on the clothing and taking them off. They expected the garments to be comfortable and convenient as well. However, it appears that the Sri Lankan apparel sector does not cater to the women with disabilities and so it is unable to meet most of these requirements presently. In this context, it is clear that there is a good case for developing garments that do not hinder body movements, incorporate convenient fastening methods, and provide maximum comfort to the wearer. Further studies are recommended to obtain more precise results by drawing samples from other provinces of Sri Lanka since this research was limited to the Western province. However, there can be no doubt that these findings will be beneficial to the apparel designers and product developers for them to gain an understanding of the special factors that need to be considered when designing garments for women with disabilities in Sri Lanka. As this study is only the starting point to identify the areas that require improvements in adaptive clothing for specific consumer groups, it is recommended that further studies be conducted on designing and developing adaptive clothing to meet future needs.

\section{References}

Ahmed, O. (2017). It's Time for Adaptive Fashion. Global Apparel Forum. Retrieved from http://globalapparelforum.com/time-adaptive-fashion/

Banks, K. (2001). Adaptive Clothing-Preserves Independence and Assists the Caregiver. Lippincott's Case Management, 6(6), 243-245. Retrieved from http://doi.org/10.1097/00129234-200111000-00004

Carroll, K. E. (2001). Innovations and improvisations: a study in specialized product development focused on business clothing for women with physical disabilities. (Doctoral dissertation, Virginia Polytechnic Institute and State University). Retrieved from https://vtechworks.lib.vt.edu/bitstream/handle/10919/26182/etd.pdf?sequence=1

Erlingsson , C. \& Brysiewicz, P. (2017). A hands-on guide to do content analysis. African Journal of Emergency Medicine, Vol 7, 93-97. Retrieved from https://www.ncbi.nlm.nih.gov/pmc/articles/PMC6234169/

Imran, A., Drean, L. S. \&Adolphe, D. (2017). Adaptive bra designs for the individuals with special needs. 17th World Textile Conference AUTEX 2017- Textiles - Shaping the Future . Retrieved from http://iopscience.iop.org/article/10.1088/1757-899X/254/7/072012/pdf

Kabel, A., McBee-Black, K. and Dimka, J. (2016). Apparel-related participation barriers: ability, adaptation and engagement. Journal of Disability and rehabilitation, 38(22), 2184-2192. Retrieved from http://doi.org/10.3109/09638288.2015.1123309

Kidd, L.K. (2006). A case study: Creating special occasion garments for young women with special needs. Clothing and Textiles Research Journal, 24(2), 161-172. Retrieved from https://doi.org/10.1177/1077727X07299675

Klerk, H. M. \& Ampousah, L. (2003). The physically disabled woman's experience of self. Journal of Disability and Rehabilitation, 25(19), 1132-1139. Retrieved from http://doi.org/10.1080/09638280310001596199

Moniuszko, S. M. (2018). Everything about adaptive apparel, the inclusive clothing trend. Retrieved from https://www.usatoday.com/story/life/2018/04/04/what-adaptive-apparel-everything-disability-friendly-clothesmainstream-inclusive/1044712001/

Radvan, C. (2013). Inclusively designed womenswear through industrial seamless technology, The journal of Design, creative process \& the fashion industry, Vol 5 (1). Retrieved from https://www.tandfonline.com/doi/pdf/10.2752/175693813X13559997788727?casa_token=WQ-

fGA0k3oYAAAAA:fj5p4eq7zuZxP-

DbDISWmiFNBEKQX10bh1V3W9KsTM2Y7ptV7P411T5vvniIWq_F5kGXw8ECPoZAFA

Sarcone, K. (2017). Marginalized Consumers Exploring Disability, Body Image, and Clothing Consumption. (Master's thesis, Brown University School of Public Health, Rhode Island). Retrieved from https://static1.squarespace.com/static/5914aedc5016e1fa958ecd79/t/5a56b86c9140b755af452455/15156327500 70/Thesis+05.01.2017+\%28Sarcone\%2C+Krystal\%29.pdf 
Schneider, C. (2015). The Clothing Line Designed to Make Disabled Dressing Easier. Retrieved from http://mentalfloss.com/article/66412/clothing-line-designed-make-disabled-dressing-easier

WHO (2011). World report on disabilities, World Health Organization . Retrieved from http://www.who.int/disabilities/world_report/2011/report.pdf

WHO (2018). Disability and health, World Health Organization. Retrieved from http://www.who.int/newsroom/fact-sheets/detail/disability-and-health

World Bank Group (2018). Disability Inclusion Overview. Retrieved from https://www.worldbank.org/en/topic/disability

Zhdanova, J. (2014). Four myths about fashion for people with disabilities. Retrieved from https://medium.com/@Zhezhda/four-myths-about-fashion-for-people-with-disabilities-8da7bbe1ab93 